\title{
Effect of linseed and rapeseed or linseed and rapeseed oil on performance, slaughter yield and fatty acid depo- sition in edible parts of the carcass in broiler chickens*
}

\author{
C.V. Nguyen, S. Smulikowska ${ }^{1}$ and A. Mieczkowska \\ The Kielanowski Institute of Animal Physiology and Nutrition, \\ Polish Academy of Sciences \\ 05-110 Jabłonna, Poland
}

(Received 20 October 2002; accepted 4 April 2003)

\begin{abstract}
The objective of the study was to investigate the effect of linseed and rapeseed or respective oils on performance indices, nutrient digestibility, metabolizable energy of diets, digesta viscosity, and yield and chemical composition of edible and non-edible parts of the carcass of broiler chickens, with particular attention to n-3 PUFA.

Two experiments were performed on 134 female broiler chickens, randomly allocated to 3 groups of 22 birds (Experiment 1) or 2 groups of 24 birds (Experiment 2) and 10 birds to a zero group. The chickens were kept in individual cages. Five wheat-based and xylanase-supplemented diets containing about $80 \mathrm{~g}$ crude fat per $\mathrm{kg}$ were prepared. The source of added fat was in control diet lard $(61 \mathrm{~g} / \mathrm{kg})$, in experimental diets half of the lard was substituted by: linseed oil (LO) or full-fat linseed (L), rapeseed oil (RO) or full-fat rapeseed (R). Chickens were given the control or experimental diets from days 8 to 42 of life, then they were slaughtered, the carcasses were divided into edible and non-edible parts, and their chemical composition determined.

Feeding diet with rapeseed did not significantly affect BWG or FCR, while linseed caused an increase in feed intake and subsequent deterioration in FCR, which in groups $\mathrm{C}, \mathrm{LO}$, and L equalled 1.82, 1.73 and 2.0, respectively. The viscosity of jejunal digesta in group L reached $4.5 \mathrm{mPas} . \mathrm{s}$ in comparison with about 1.5 in all of the remaining groups. Organic matter retention and $\mathrm{AME}_{\mathrm{N}} \mathrm{va-}$ lue of diet $\mathrm{L}$ was lower than in diets $\mathrm{C}$ and $\mathrm{LO}(\mathrm{P} \leq 0.05)$, while apparent protein and fat digestibility, organic matter retention, and the $\mathrm{AME}_{\mathrm{N}}$ value of diet $\mathrm{R}$ was lower than $\mathrm{RO}(\mathrm{P} \leq 0.01)$. Protein retention and meat yield was lower in group $\mathrm{L}$ than in both of the other groups $(\mathrm{P} \leq 0.05)$. The deposition
\end{abstract}

\footnotetext{
* Supported in part by the State Committee for Scientific Research, Grant No. 5 P06E 03115

${ }^{1}$ Corresponding author: e-mail s.smulikowska@ifzz.pan.pl
} 
of n-3 PUFA in the carcass was in groups R and RO 2 times greater, in groups L and LO 8 times greater than in the control group. The ratio of n-6/n-3 PUFA, which approximated 10 in edible parts of broilers from the control group, decreased to about 4.7 in groups $\mathrm{R}$ and $\mathrm{RO}$, and to about 1.3 in groups L and LO. This shift may be considered favourable for consumers of broiler meat, as an increase of n-3 fatty acid intake is connected with health benefits in humans.

KEY WORDS: linseed, rapeseed, digesta viscosity, n-3 PUFA, carcass, broiler chickens

\section{INTRODUCTION}

In human diets there is an imbalance in ratio of $n-6 / n-3$ polyunsaturated fatty acids (PUFA) and increasing consumption of n-3 PUFA is recommended. Enrichment of poultry products with n-3 PUFA may provide an excellent alternative food source of these acids in the human diet due to its relative availability and affordability (Van Elswyk, 1997). In the lipids of most cereals used in intensive poultry production, the content of linoleic acid $\left(\mathrm{C}_{18: 2 \mathrm{n}-6}\right)$ is high and $\alpha$-linolenic acid (LNA - $\left.\mathrm{C}_{18: 3 \mathrm{n}-3}\right)$ is low and as a result, the proportion n-6 to n-3 fatty acids in poultry products is high as well. Among oilseeds produced in Poland linseed is very rich in LNA, rapeseed contain moderate levels of these fatty acids. Both oilseeds may be used to enrich poultry products with n-3 PUFA (Ajuyah et al., 1991; Pietras et al., 2000; Barteczko and Borowiec, 2001). However, both oilseeds contain several antinutritional factors, which may negatively affect performance of chickens. The most important ones in linseed are linatine, which acts as a pyridoxine antagonist (Klosterman, 1974), mucilage, which form very viscous solutions (Mazza and Biliaderis, 1989), there are also some trypsin inhibitors, goitrogens, and phyto-oestrogenic compounds, also known as plant lignans (Van Elswyk, 1997). Rapeseed 00 contains glucosinolates, erucic acid, tannins and phytates (Matyka et al., 1992; Korol et al., 1994, Wałkowski et al., 2000-2001). Different limits have been proposed for the level of rapeseed and linseed in broiler chicken diets. Leeson et al. (1987) and Kracht et al. (1995) suggested that a safe level of full-fat rapeseed in broiler diet is $100 \mathrm{~g} / \mathrm{kg}$, at rates higher than $150 \mathrm{~g} / \mathrm{kg}$ the feed intake and performance of chickens might be reduced. In contrast, Lee et al. (1991) reported that feeding diets containing 100 or $200 \mathrm{~g} / \mathrm{kg}$ full-fat canola did not significantly decrease performance of chickens in comparison with the control group. Increased dietary inclusion of linseed led to poor digestibility and utilization of nutrients by chickens (Ortiz et al., 2001, Rodriguez et al., 2001), a significant decrease in the body weight gain (BWG), feed conversion ratio (FCR) and breast muscle yield (Ajuyah et al., 1991; Lee et al., 1991). The antinutrients of linseed are not destroyed by heat treatment (Lee et al., 1991), so Roth-Maier (1998) postulated that not more than 5\% of linseed should be included into broiler diets to avoid the decrease in growth performance. Our former observations proved that this limit may be raised. After supplementation 
a diet containing $8 \%$ of linseed with additional pyridoxine $(4 \mathrm{mg} / \mathrm{kg})$ the depressive effect of linseed on BWG was completely alleviated (Nguyen et al., 2001).

The objective of this study was to examine the effect of moderate dietary levels of linseed and rapeseed or their respective oils on performance indices, nutrient digestibility, metabolizable energy of diets, digesta viscosity and yield and chemical composition of edible and non-edible parts of the carcass of broiler chickens, with particular attention to n-3 PUFA.

\section{MATERIAL AND METHODS}

Commercial brown-seeded linseed and rapeseed ' 00 ', linseed oil, rapeseed oil and lard were used as a source of supplementary fat in diets. Five wheat-based and xylanase-supplemented diets containing about $80 \mathrm{~g}$ crude fat per $\mathrm{kg}$ were used (Table 1). The source of added fat in the control diet (C) was lard, in the experimental diets part of the lard was substituted by full-fat linseed (diet L), linseed oil (diet LO), full-fat rapeseed (diet R), or rapeseed oil (diet RO). The diet with linseed was additionally fortified with $4 \mathrm{mg} / \mathrm{kg}$ pyridoxine. Linseed and rapeseed were finely ground, all components of diets were mixed and cold pelleted on a CL-2 CPM Laboratory Pellet Mill. The diets used in balance experiments were of the same composition as Starter diets (Table 1), but prior to mixing $3 \mathrm{~g} \mathrm{Cr}_{2} \mathrm{O}_{3}$ per $\mathrm{kg}$ was added as a marker.

Two experiments were performed on 8-day-old female broiler chickens of the Cobb line, fed during the first week of life with a standard Starter diet. At day 8 of age the birds were deprived of feed for $4 \mathrm{~h}$ and weighed. Then in Experiment 1 the chickens were allocated randomly to the zero group (10 birds) and to groups $\mathrm{C}, \mathrm{L}$ and LO (22 birds in each). Mean initial body weight in the groups was 163 $\pm 9 \mathrm{~g}$. In Experiment 2 they were allocated randomly to the zero group (10 birds) and to groups R and RO (24 birds in each). Mean initial body weight in the groups was $144 \pm 8 \mathrm{~g}$.

The birds from the zero group were killed and carcasses were stored at $-18^{\circ} \mathrm{C}$ for later analyses. The remaining birds were placed in individual cages $(38 \times 50$ x $50 \mathrm{~cm}$ ), equipped with an electrical heater inside, trough and water cup outside and a tray underneath for collection of droppings. Each bird was treated as a replicate. Birds were fed ad libitum respective Starter diets (Table 1), body weight and feed intake were recorded in weekly intervals.

On day 22 of life, the chickens in each group were divided into 2 subgroups. A balance experiment was performed according to Bourdillon et al. (1990) on the first subgroup (10 chickens) with the use of respective Starter diets (Table 1) containing $3 \mathrm{~g} / \mathrm{kg}$ of $\mathrm{Cr}_{2} \mathrm{O}_{3}$ added as a marker. Droppings from each bird were collected quantitatively for 4 days of feeding and following $17 \mathrm{~h}$ starvation and stored 
恶

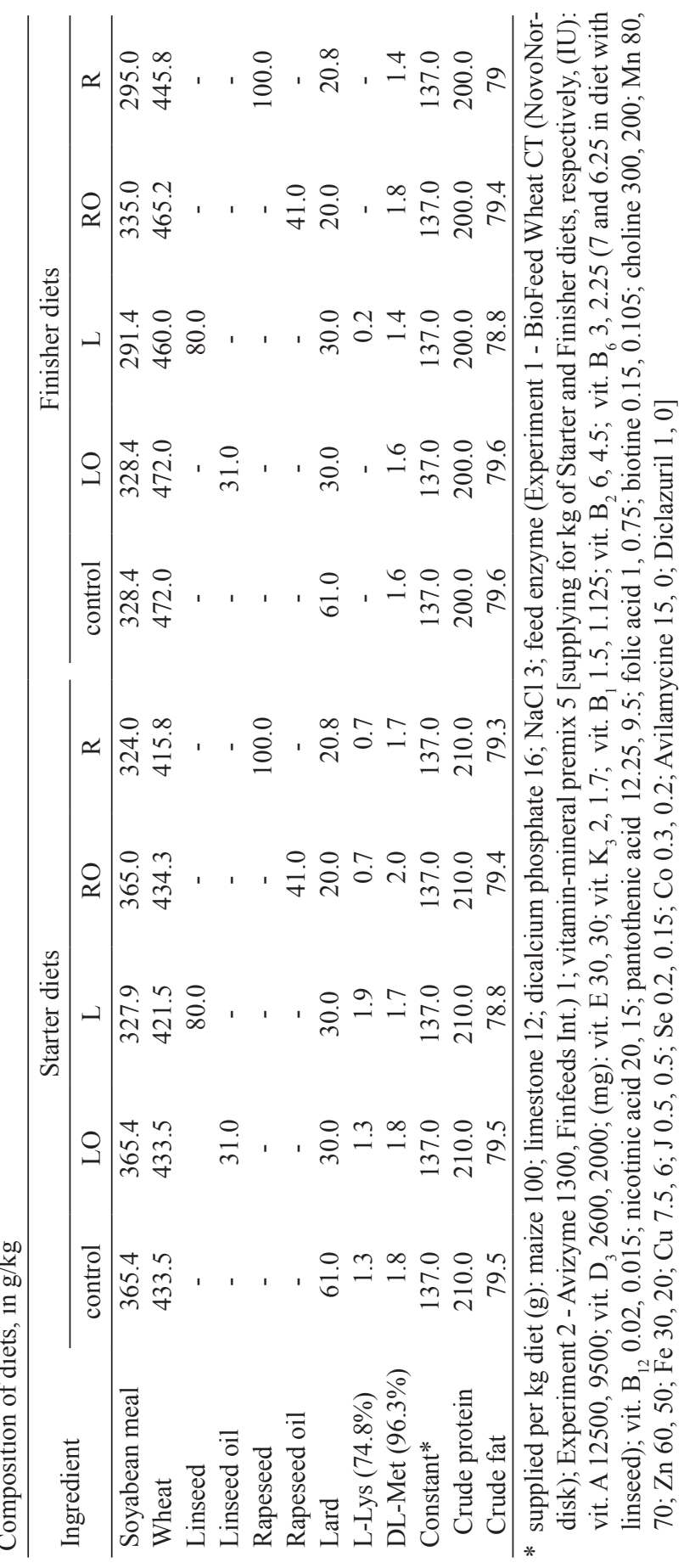


at $-18^{\circ} \mathrm{C}$. After refeeding on day 31 of age the birds were killed by decapitation. The abdominal cavity was opened and digesta from the jejunum, ileum and caeca was taken. Digesta from the jejunum was centrifuged at $10,000 \mathrm{x} g$ for 10 min using a Beckman centrifuge (model $\mathrm{J} 2-21$ with a $\mathrm{J}-20$ rotor) at $4^{\circ} \mathrm{C}$, and the viscosity of the supernatant was immediately measured with the use of a Brookfield Digital cone/plate viscometer (model LVDV II+, Brookfield Engineering Laboratories, Stoughton, MA, USA) at $40^{\circ} \mathrm{C}$. Readings were expressed in centipoise $(\mathrm{cP}=1 \mathrm{mPas} \cdot \mathrm{s})$. Ileal and caecal contents were mixed with deionised water in a proportion of $1: 1 \mathrm{w} / \mathrm{w}$ and their $\mathrm{pH}$ was immediately measured by a digital $\mathrm{pH}$-meter (Hand-Held Meter, model WTW pH/340, Germany) using pH standard WTW D-82362 Weilheim (model STP4) at room temperature.

The second subgroup was fed ad libitum respective Starter diets up to 36 day of life and a Finisher diet during the last week (Table 1); body weight and feed intake were measured as described previously. At the end of the experiment ten birds from each group were deprived of food for $12 \mathrm{~h}$, weighed, slaughtered, dry plucked and eviscerated. Carcass and breast muscles were weighed, and the whole body was manually divided into 3 samples of edible and 2 samples of non-edible parts. Edible parts consisted of: meat (breasts and other meat separated manually from bones), skin with abdominal fat, and edible giblets (liver, heart and stomach). Non-edible parts consisted of: head, blood, legs, bones and non-edible giblets, feathers were collected separately. All samples were weighed and stored in plastic bags at $-18^{\circ} \mathrm{C}$ for later analyses. Feathers from each bird were immediately chopped, mixed and pooled; $100 \mathrm{~g}$ samples from each group were prepared.

\section{Chemical analysis}

Prior to analysis the droppings were homogenized, dried for $12 \mathrm{~h}$ at $60^{\circ} \mathrm{C}$, kept open for $48 \mathrm{~h}$ and ground to pass a $1 \mathrm{~mm}$ sieve. Carcasses of the zero group, feathers, and non-edible parts of carcasses were thawed and placed in weighed glass jars containing, respectively, 50, 100 or $150 \mathrm{~g} 5 \%$ solution (w/w) of citric acid. The samples then were autoclaved; feathers for $14 \mathrm{~h}$, non-edible parts of carcass and zero samples for $4 \mathrm{~h}$ at $1.2 \mathrm{~atm}$; cooled off and homogenized. Samples of meat, edible giblets and skin with abdominal fat were minced, frozen and homogenized immediately before analysis.

The chemical composition of linseed, rapeseed, droppings and carcass parts was determined according to AOAC (1990). Linseed mucilage was extracted according to Mazza and Biliaderis (1989). Glucosinolates in rapeseed were analysed by HPLC according to ISO-9167 (1991). Crude fat in samples of diets and droppings was determined by diethyl ether extraction following acidification with $4 \mathrm{M}$ hydrochloric acid. Gross energy content in diets and droppings was determined using a Parr adiabatic oxygen bomb calorimeter (KL-11), $\mathrm{Cr}_{2} \mathrm{O}_{3}$ was analysed spectropho- 
tometrically following wet ashing according to Hinsberg et al. (1953). Faecal N in droppings was determined according to Ekman et al. (1949).

For analysis of fatty acid composition, all 5 parts of chicken bodies were pooled within a group (the same amount of dry matter was taken from each individual sample) and homogenized. One gram of the sample was extracted with chloroform-methanol $(2: 1 \mathrm{v} / \mathrm{v})$ according to Folch et al. (1957). Fatty acid methyl esters were separated and measured using a Hewlett-Packard gas chromatograph model 5890 series II, equipped with flame ionization detector, a column $30 \mathrm{~m}$ x $0.32 \mathrm{~mm}$ internal diameter, $0.25 \mu \mathrm{m}$ film thickness. The analyses were performed in triplicate according to Rotenberg and Andersen (1980) and Paterson and Amado (1997).

\section{Calculations and statistical analysis}

Apparent digestibility of protein, fat, organic matter retention and metabolizable energy $\left(\mathrm{AME}_{\mathrm{N}}\right)$ of diets were calculated relative to the content of $\mathrm{Cr}_{2} \mathrm{O}_{3}$ in diets and droppings. $\mathrm{AME}_{\mathrm{N}}$ values of diets were calculated from the gross energy values of diets and droppings and corrected to zero nitrogen values using $34.39 \mathrm{~kJ} / \mathrm{g}$ nitrogen retained (Hill and Anderson, 1958). Deposition of fatty acids in the whole body of 6 week-old chickens was calculated by subtracting the initial content of respective fatty acids (determined in zero samples) from the fatty acid content in the whole body of slaughtered birds. The total fatty acid (FA) content in tissue lipids equals the content of crude fat $\mathrm{x} 0.965$.

Means and pooled standard error of means (SEM) were calculated by standard procedures, the data were subjected to one-way analysis of variance (ANOVA) generated by Statgraphics ${ }^{\circledR}$ ver. 5.1. Duncan's multiple range test was used to compare differences between means.

\section{RESULTS}

The chemical composition of linseed and rapeseed used in the current study and its fatty acid profile are shown in Table 2. Growth performance of broiler chickens is shown in Table 3. There was no mortality during Experiment 1, but one bird died and two were culled during Experiment 2. In Experiment 1 chickens from group L gained less $(\mathrm{P} \leq 0.05)$ than the control group during the finisher period, but differences in total BWG among groups were insignificant. Chickens in group L consumed more feed than in the remaining groups $(\mathrm{P} \leq 0.05)$, so the FCR in group $\mathrm{L}$ was $10 \%$ worse than in the control group and $16 \%$ worse $(\mathrm{P} \leq 0.05)$ than in group LO. In Experiment 2, feed intake was a little higher, body weight gain lower and FCR numerically worse in group $\mathrm{R}$ in comparison with group RO, but these differences did not reach statistically significant levels. 
TABLE 2

Chemical composition of linseed and rapeseed, g/kg DM

\begin{tabular}{lrc}
\hline Component & Linseed & Rapeseed \\
\hline Dry matter, g/kg & 921.2 & 939.8 \\
Crude protein $(\mathrm{N} \times$ x.25) & 223.9 & 210.1 \\
Crude ash & 36.7 & 41.6 \\
Crude fat & 422.1 & 438.6 \\
Starch & 2.6 & 7.5 \\
Sugar & 31.0 & 14.5 \\
Crude fibre & 183.4 & 71.1 \\
TDF $^{1}$ & 283.7 & 287.7 \\
Mucilages & \\
Glucosinolates, $\mu \mathrm{M} / \mathrm{g}$ DM $^{3}$ & 97.8 & 15.7 \\
Major fatty acids, \% of total & & \\
$\mathrm{C}_{16: 0}$ & & \\
$\mathrm{C}_{18: 0}$ & & 4.29 \\
$\mathrm{C}_{18: 1}$ & 4.97 & 1.65 \\
$\mathrm{C}_{18: 2 \mathrm{n}-6}$ & 3.63 & 59.37 \\
$\mathrm{C}_{18: 3 \mathrm{n}-3}$ & 18.62 & 20.14 \\
$\mathrm{C}_{20: 1}$ & 15.37 & 9.84 \\
$\mathrm{C}_{22: 1}$ & 55.99 & 1.87 \\
Other fatty acids & 0.17 & 1.08 \\
\hline
\end{tabular}

${ }^{1}$ total dietary fibre calculated as follows: TDF $=1000$ - crude protein - crude ash - crude fat - sugars - starch

${ }^{2}$ determined according Mazza and Biliaderis (1989) and contained (in g/kg DM): crude protein 18.9; crude ash 7.7; crude fat 0.2 ; nitrogen-free extractives 71.0

${ }^{3}$ determined according to ISO-9167-1 (1991)

${ }^{4}$ in it: $\mathrm{C}_{14: 0} 0.04, \mathrm{C}_{16: 1} 0.07, \mathrm{C}_{17: 0} 0.06, \mathrm{C}_{17: 1} 0.06, \mathrm{C}_{20: 0} 0.17, \mathrm{C}_{20: 3 \mathrm{n}-6} 0.04, \mathrm{C}_{22: 0} 0.15$

${ }^{5}$ in it: $\mathrm{C}_{14: 0} 0.06, \mathrm{C}_{16: 1} 0.22, \mathrm{C}_{17: 0} 0.08, \mathrm{C}_{17: 1} 0.02, \mathrm{C}_{20: 0}^{20: 0} 0.68, \mathrm{C}_{20: 2 \mathrm{n}-6}^{20: 3 \mathrm{n}-6} 0.12, \mathrm{C}_{22: 0}^{22: 0} 0.44, \mathrm{C}_{24: 0} 0.23$, $\mathrm{C}_{24: 1}^{14.0} 0.17$

TABLE 3

Performance of chickens from 8 to 42-day-old (days 8-35 Starter diets, days 36-42 Finisher diets)

\begin{tabular}{|c|c|c|c|c|c|c|c|c|c|}
\hline \multirow{2}{*}{$\begin{array}{l}\text { Dietary } \\
\text { treatment }\end{array}$} & \multicolumn{3}{|c|}{ Body weight gain, $g$} & \multicolumn{3}{|c|}{ Feed intake, $\mathrm{g}$} & \multicolumn{3}{|c|}{ FCR, $g$ feed/g BWG } \\
\hline & $8-35$ & $36-42$ & $8-42$ & $8-35$ & $36-42$ & $8-42$ & $8-35$ & $36-42$ & $8-42$ \\
\hline \multicolumn{10}{|l|}{ Experiment 1} \\
\hline Control & 1726 & $483^{\mathrm{a}}$ & 2208 & $2904^{a}$ & 1110 & $4014^{\mathrm{a}}$ & $1.68^{\mathrm{b}}$ & $2.32^{\mathrm{a}}$ & $1.82^{\mathrm{a}}$ \\
\hline Linseed oil & 1743 & $465^{\mathrm{ab}}$ & 2208 & $2781^{\mathrm{a}}$ & 1045 & $3827^{\mathrm{a}}$ & $1.60^{\mathrm{a}}$ & $2.25^{\mathrm{a}}$ & $1.73^{\mathrm{a}}$ \\
\hline Linseed & 1764 & $415^{\mathrm{b}}$ & 2179 & $3199^{b}$ & 1149 & $4348^{b}$ & $1.82^{\mathrm{c}}$ & $2.78^{\mathrm{b}}$ & $2.00^{\mathrm{b}}$ \\
\hline Pooled SEM & 35 & 18 & 46 & 75 & 37 & 106 & 0.03 & 0.08 & 0.03 \\
\hline \multicolumn{10}{|l|}{ Experiment 2} \\
\hline Rapeseed oil & 1840 & 496 & 2337 & 2835 & 1062 & 3897 & 1.55 & 2.16 & 1.67 \\
\hline Rapeseed & 1768 & 556 & 2324 & 2792 & 1128 & 3921 & 1.58 & 2.05 & 1.69 \\
\hline Pooled SEM & 48 & 21 & 63 & 52 & 24 & 85 & 0.01 & 0.13 & 0.03 \\
\hline
\end{tabular}

${ }_{\mathrm{a}, \mathrm{b}}$ means in a column with no common superscripts are significantly different at $\mathrm{P} \leq 0.05$. In experiment 2 all differences between groups were not significant 
TABLE 4

Apparent protein digestibility (APD), apparent fat digestibility (AFD), organic matter retention $(\mathrm{OMR})$, metabolizable energy $\left(\mathrm{AME}_{\mathrm{N}}\right)$ of diets, viscosity of jejunal digesta (in mPas.s) and $\mathrm{pH}$ in ileal and caecal digesta in 31 day-old broiler chickens fed Starter diets

\begin{tabular}{|c|c|c|c|c|c|c|c|}
\hline \multirow{2}{*}{$\begin{array}{l}\text { Dietary } \\
\text { treatment }\end{array}$} & \multirow{2}{*}{$\begin{array}{c}\text { APD } \\
\%\end{array}$} & \multirow{2}{*}{$\begin{array}{c}\text { AFD } \\
\%\end{array}$} & \multirow{2}{*}{$\begin{array}{c}\text { OMR } \\
\%\end{array}$} & \multirow{2}{*}{$\begin{array}{c}\mathrm{AME}_{\mathrm{N}} \\
\mathrm{MJ} / \mathrm{kg} \\
\mathrm{DM}\end{array}$} & \multirow{2}{*}{$\begin{array}{l}\text { Viscosity } \\
\text { of jejunal } \\
\text { digesta }\end{array}$} & \multicolumn{2}{|c|}{$\mathrm{pH}$ of digesta in } \\
\hline & & & & & & ileum & caeca \\
\hline \multicolumn{8}{|l|}{ Experiment 1} \\
\hline Control & 93.2 & 86.1 & $71.7^{\mathrm{c}}$ & $14.8^{\mathrm{b}}$ & $1.59^{\mathrm{a}}$ & 7.53 & 6.42 \\
\hline Linseed oil & 92.8 & 86.5 & $70.2^{\mathrm{b}}$ & $14.7^{\mathrm{b}}$ & $1.54^{\mathrm{a}}$ & 7.43 & 6.69 \\
\hline Linseed & 93.1 & 84.8 & $68.6^{\mathrm{a}}$ & $14.1^{\mathrm{a}}$ & $4.53^{\mathrm{b}}$ & 7.10 & 6.68 \\
\hline Pooled SEM & 0.20 & 0.55 & 0.50 & 0.12 & 0.05 & 0.12 & 0.15 \\
\hline \multicolumn{8}{|l|}{ Experiment 2} \\
\hline Rapeseed oil & $88.6^{\mathrm{B}}$ & $84.7^{\mathrm{B}}$ & $76.1^{\mathrm{B}}$ & $15.6^{\mathrm{B}}$ & 1.54 & $8.20^{\mathrm{B}}$ & 5.32 \\
\hline Rapeseed & $86.4^{\mathrm{A}}$ & $75.8^{\mathrm{A}}$ & $72.4^{\mathrm{A}}$ & $14.6^{\mathrm{A}}$ & 1.59 & $7.34^{\mathrm{A}}$ & 5.32 \\
\hline Pooled SEM & 0.28 & 0.85 & 0.51 & 0.09 & 0.05 & 0.20 & 0.08 \\
\hline
\end{tabular}

In group $\mathrm{L}$, the $\mathrm{AME}_{\mathrm{N}}$ value and organic matter retention were significantly lower $(\mathrm{P} \leq 0.05)$, apparent fat digestibility was numerically lower, and apparent protein digestibility was similar in comparison with the control and LO groups (Table 4). The viscosity of jejunal digesta was about 3 times higher in $\mathrm{L}$ than in both of the other groups, but there were no differences between groups in average $\mathrm{pH}$ of ileal and caecal contents. The apparent fat digestibility, organic matter retention and apparent protein digestibility were lower in group $\mathrm{R}$ than in $\mathrm{RO}(\mathrm{P} \leq 0.01)$. This resulted in a lower metabolizable energy $\left(\mathrm{AME}_{\mathrm{N}}\right)$ value of diet $\mathrm{R}(\mathrm{P} \leq 0.01)$. In both groups the viscosity of jejunal digesta was similar to that in the control and LO groups in Experiment 1, while the $\mathrm{pH}$ of ileal digesta was significantly $(\mathrm{P} \leq 0.01)$ lower in group R than in group RO (Table 4).

Slaughter yield (hot carcass weight relative to LBW) in all groups averaged $73 \%$. After dissection, from 57 to $60 \%$ of LBW was qualified as edible parts, from 29 to $33 \%$ of LBW as non-edible parts of the carcass, about $5 \%$ of LBW were feathers (Table 5). The breast muscle and meat yield was lowest in group $\mathrm{L}(\mathrm{P} \leq 0.05)$. There were no distinct differences in the chemical composition of parts of the carcass among groups (data not shown), the meat portion contained from 19.5 to $20.1 \%$ crude protein and from 7.1 to $8.2 \%$ crude fat, skin and abdominal fat from 8.3 to $9.5 \%$ crude protein and 50 to $58 \%$ crude fat, however, in all parts of the carcass the highest level of crude fat was in L chickens. The content of ash in non-edible parts of the carcass was lower in groups $\mathrm{R}(4.9 \%)$ and $\mathrm{L}(5.1 \%)$ in comparison with $5.5 \%$ in the remaining groups $(\mathrm{P} \leq 0.05)$. Total protein retention in a body was significantly $(\mathrm{P} \leq 0.05)$ lower in $\mathrm{L}$, while energy retention was lower $(\mathrm{P} \leq 0.05)$ in group $\mathrm{R}$, in comparison with the remaining groups (Table 5). 


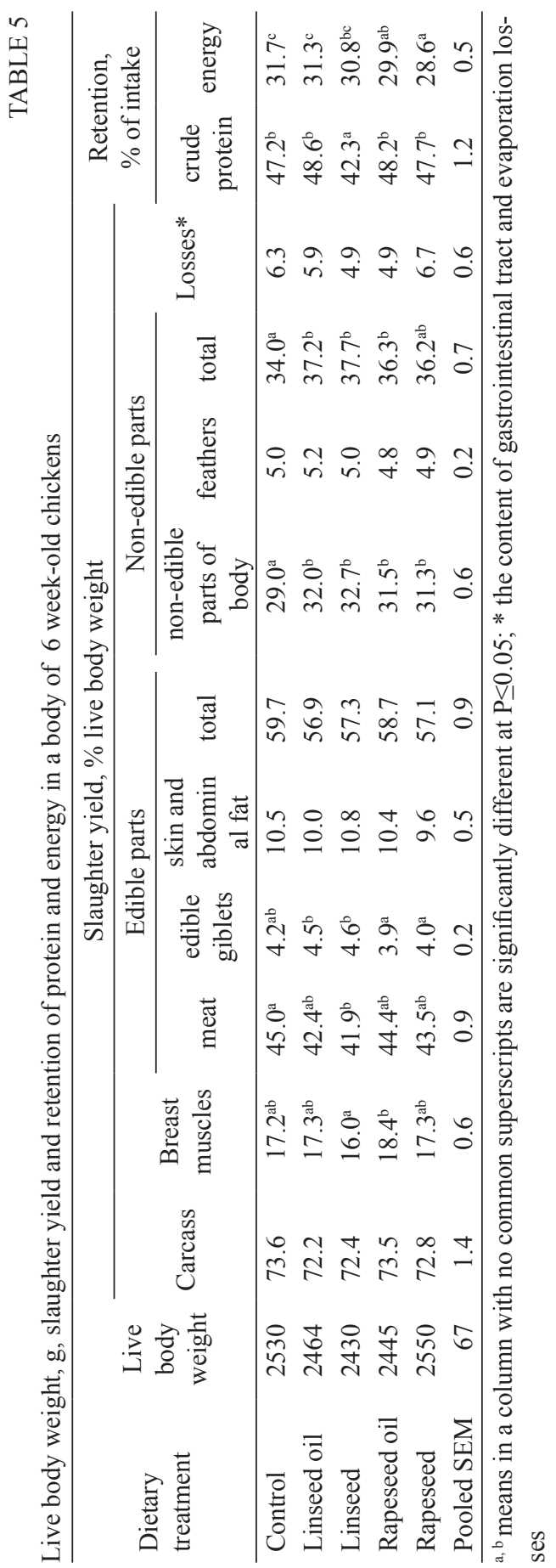


TABLE 6

Major fatty acids in Starter diets, \% of total fatty acids

\begin{tabular}{lrrrrrr}
\hline \multirow{2}{*}{ Fatty acid } & \multicolumn{3}{c}{ Experiment 1} & & \multicolumn{2}{c}{ Experiment 2 } \\
\cline { 2 - 4 } \cline { 6 - 7 } & control & \multicolumn{1}{c}{ LO } & \multicolumn{1}{c}{$\mathrm{L}$} & & \multicolumn{1}{c}{ RO } & \multicolumn{1}{c}{$\mathrm{R}$} \\
\hline $\mathrm{C}_{16: 0}$ & 18.71 & 13.04 & 13.57 & & 10.18 & 11.06 \\
$\mathrm{C}_{18: 0}$ & 10.12 & 7.15 & 7.23 & & 4.70 & 5.69 \\
$\mathrm{C}_{16: 1}$ & 1.85 & 1.00 & 0.98 & & 0.73 & 0.74 \\
$\mathrm{C}_{18: 1}$ & 43.74 & 34.42 & 31.73 & & 48.84 & 47.79 \\
$\mathrm{C}_{22: 1}$ & $\mathrm{nd}$ & $\mathrm{nd}$ & $\mathrm{nd}$ & & 0.51 & 0.61 \\
$\mathrm{C}_{18: 2 \mathrm{n}-6}$ & 18.83 & 21.89 & 21.18 & & 24.19 & 24.28 \\
$\mathrm{C}_{20: 4 \mathrm{n}-6}$ & 0.17 & 0.08 & 0.09 & & 0.08 & 0.08 \\
$\mathrm{C}_{18: 3 \mathrm{n}-3}$ & 1.53 & 18.72 & 21.81 & & 5.15 & 5.48 \\
& & & & & & \\
SFA & 30.22 & 21.19 & 21.80 & & 16.29 & 18.27 \\
MUFA & 47.11 & 36.39 & 33.62 & & 51.97 & 50.90 \\
PUFA & 21.18 & 40.96 & 43.39 & & 29.64 & 30.09 \\
PUFA n-6/n-3 & 12.23 & 1.19 & 0.99 & & 4.75 & 4.45 \\
\hline
\end{tabular}

diets with: LO - linseed oil ; L - linseed; RO - rapeseed oil; R - rapeseed

SFA - total saturated-; MUFA - total monounsaturated-; PUFA - total polyunsaturated fatty acids nd - non detected

The total dietary crude fat content was similar in all diets (Table 1), but due to substitution of half of the lard by rapeseed oil in diets $\mathrm{RO}$ and $\mathrm{R}$ or by linseed oil in diets $\mathrm{LO}$ and $\mathrm{L}$, the content of SFA decreased, while the content of $\alpha$-linolenic acid increased and the ratio of n-6/n-3 PUFA decreased substantially in comparison with the control diet. The fatty acid profile in Finisher diets was similar as in Starter diets (Table 6).

The fatty acid profile was determined in all portions of the carcass, but only that of meat and skin with abdominal fat are shown in Table 7. The SFA content in lipids of meat, skin with abdominal fat and non-edible parts of carcass ranged from $29 \%$ in the control group to about 24 in groups $\mathrm{R}$ and $\mathrm{RO}$, and $25-26 \%$ in groups $\mathrm{LO}$ and L; in the lipids of edible giblets it ranged from 28 to $32 \%$. The share of MUFA in total FA in groups RO and R was similar to the control group, but in groups LO and L it was lower by 7 to 10 percentage points. The share of PUFA was about $16 \%$ in the control group, while in groups $\mathrm{RO}$ and $\mathrm{R}$ it was 6-7, in groups LO and L, 12-14 percentage points higher. The amount of PUFA with chains longer than 18 carbon atoms in lipids of the skin with abdominal fat was negligible, however, small amounts of erucic acid were present in all portions of chickens from groups R and RO. The n-6/n-3 PUFA ratio in edible and non-edible parts of carcass was from 7.3 to 8.3 in the control group, 4.7 to 5.4 in groups RO and R, and 1.1 to 1.6 in groups LO and L. In the lipids of feathers the proportion of SFA was higher (48-52\%), MUFA and PUFA lower (30-35 and 10-13\%, respectively), than in the remaining parts of the carcass. 





In the body of chickens from groups $\mathrm{L}, \mathrm{LO}, \mathrm{R}$ and $\mathrm{RO}$, significantly less SFA and more PUFA were deposited than in chickens from the control group $(\mathrm{P} \leq 0.05)$. Table 8 shows the intake of n- 6 and n-3 PUFA and their deposition in whole body and in edible parts of carcass. In the control group the intake of n-3 PUFA was significantly lower in comparison with all of the remaining groups $(\mathrm{P} \leq 0.01)$, the intake of n-6 PUFA was also lower, but the differences among groups were smaller $(\mathrm{P} \leq 0.05)$. In comparison with total intake, $114 \%$ of $n-3$ PUFA and $87 \%$ of $n-6$ PUFA was found in the body of control chickens, the respective values were from 64 to $75 \%$ of n-3 PUFA and from 72 to $81 \%$ of n-6 PUFA in remaining groups. Linoleic and linolenic acids, respectively, amounted to 83 and $9 \%$ of PUFA deposited in the control group, and on average 52 and $44 \%$ of PUFA in groups L and LO. The deposition of arachidonic acid $\left(\mathrm{C}_{20: 4 n-6}\right)$ was lower, but eicosapentaenoic acid $\left(\mathrm{C}_{20: 5 n-3}\right)$, higher in the body of chickens from groups $\mathrm{L}$ and $\mathrm{LO}$ than in the control group.

\section{DISCUSSION}

The chemical composition of linseed and rapeseed used in the current study and its fatty acid profile were within the range of published values for brown-seeded cultivars (Matyka et al., 1992; Korol et al., 1994; Borowiec et al., 2001). In linseed, PUFA made up over $70 \%$ of total FA, the proportion of $n-6 / n-3$ PUFA was 0.28 . The mucilage concentration ( $98 \mathrm{~g} / \mathrm{kg} \mathrm{DM}$ ) was higher than the $89 \mathrm{~g} / \mathrm{kg}$ DM reported by Mazza and Biliaderis (1989) and $75 \mathrm{~g} / \mathrm{kg}$ DM reported by Rodriguez et al. (2001). In rapeseed, PUFA made up 30\% of total FA, the proportion of n-6/n-3 PUFA was about 2 . The level of the main antinutrients, glucosinolates and erucic acid, did not exceed the levels qualifying rapeseed as ' 00 ' variety. The amount of glucosinolates in the $\mathrm{R}$ diet $(1.47 \mu \mathrm{M} / \mathrm{g})$ did not exceed the limit of $1.5 \mu \mathrm{M} / \mathrm{g}$ permitted in broiler diets (Wałkowski et al., 2000-2001).

The effect of including rapeseed into the diet on BWG and FCR was small and insignificant, which proves that the antinutrients of rapeseed did not disturb any vital function of young birds. There are many reports that levels of full-fat canola or ' 00 ' rapeseed reaching 100 or even $150 \mathrm{~g} / \mathrm{kg}$ diet did not result in a significant decline of BWG and FCR in comparison with a control group (Leeson et al., 1987; Ajuyah et al., 1991; Lee et al., 1991; Kracht et al., 1995; Pietras et al., 2000), however, higher levels of rapeseed in some of the above reports resulted in performance decline. In contrast, some authors reported that diets containing 100-200 $\mathrm{g}$ flaxseed $/ \mathrm{kg}$ (Lee et al., 1991) or 50-250 g linseed/kg (Roth-Maier et al., 1998) depressed BWG in broilers. These negative effects may be partly explained by the presence of linatine (pyridoxine antagonist) in the seeds. In our previous study (Nguyen et al., 2001) an additional supplement of pyridoxine $(4 \mathrm{mg} / \mathrm{kg}$ diet $)$ completely alleviated the 


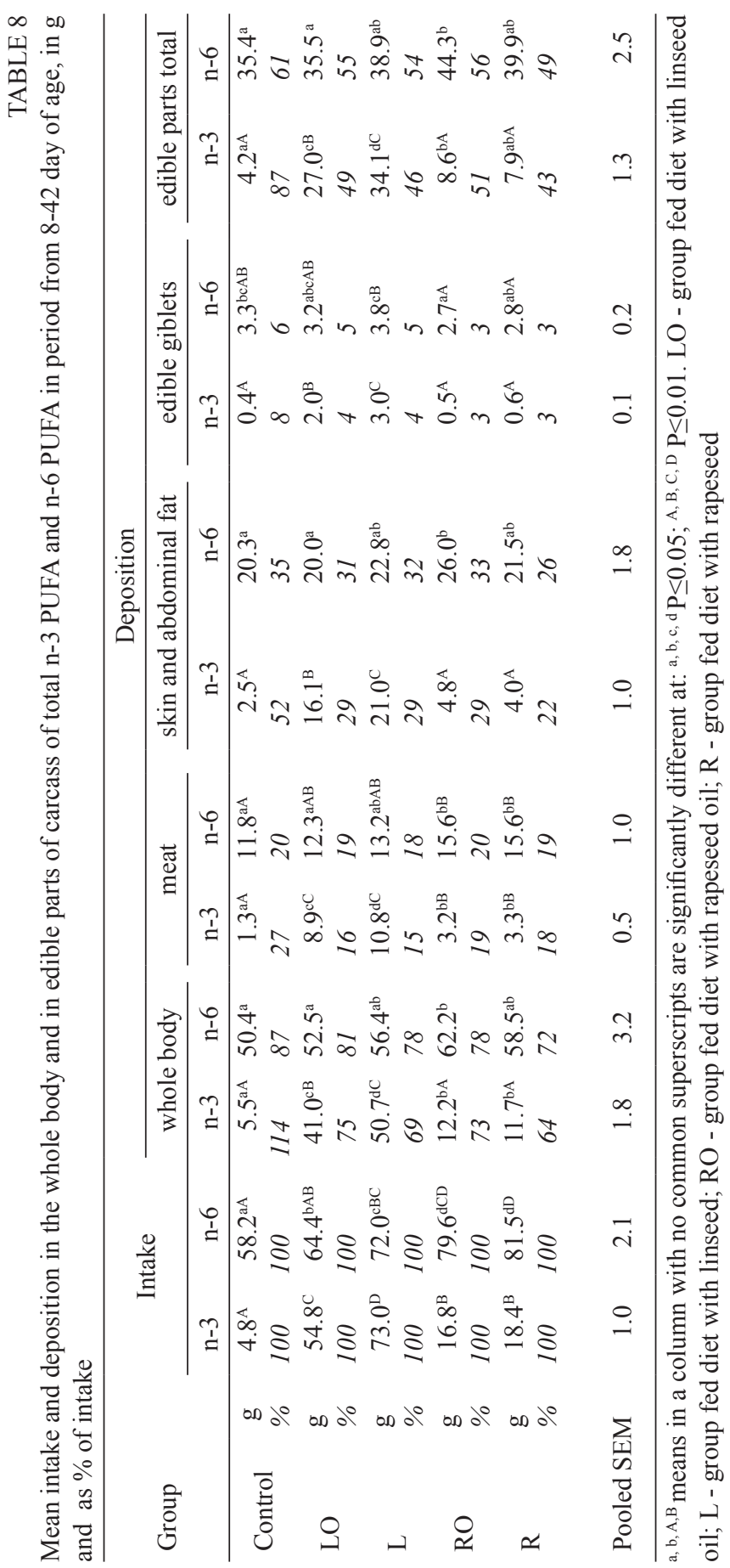


slight growth depression caused by inclusion $80 \mathrm{~g}$ linseed/ $\mathrm{kg}$ of diet containing $3 \mathrm{mg} /$ pyridoxine, so in the present experiment the diet with linseed was supplemented with pyridoxine to a level of $7 \mathrm{mg} / \mathrm{kg}$, which is double the requirements of broiler chickens according to NRC (1994). The similar final BWG in group L in comparison with the control and LO groups proved that the other antinutrients of linseed at this dietary level did not disturb any vital functions of the growing chickens. Similarly Pietras et al. (2000) reported that including 60 or $150 \mathrm{~g} / \mathrm{kg}$ linseed into broiler diets had no negative effect on BWG.

However, due to higher feed intake in group L, FCR was worse by $10 \%$, while in group LO, it was $5 \%$ better than in the control group. Also Lee et al. (1991), Olomu and Baracos (1991) and Roth-Maier et al. (1998) reported that diets with linseed depressed FCR due to higher feed intake. It seems that most of the deleterious effect of linseed on feed utilization in chickens may be attributed to water-soluble components containing mucilage. Madhusudhan et al. (1986) showed that after extraction of linseed meal with boiling water and subsequent removal of watersoluble components by centrifugation, the performance of chickens increased substantially and was superior to the control group.

In the present study, due to the inclusion of $80 \mathrm{~g}$ linseed $/ \mathrm{kg}$ diet the viscosity in jejunal digesta increased about three times in comparison with the control group, and depressed organic matter retention and $\mathrm{AME}_{\mathrm{N}}$ value of diet $\mathrm{L}$, while substitution of half of the lard with linseed oil hardly affected either digesta viscosity or digestibility of nutrients. This confirms that nutrient utilization in diet L was negatively affected by linseed mucilage. The mucilage found in the hull of linseed are heterogenic polysaccharides with functional properties similar to that of gum arabic and their solutions are very viscous (Mazza and Biliaderis, 1987). Also Rodriguez et al. (2001) reported that on a maize-based diet containing $80 \mathrm{~g}$ linseed/ $\mathrm{kg}$ the viscosity of jejunal digesta was about four times higher than in control chickens, which lowered apparent nitrogen retention, fat digestibility and $\mathrm{AME}_{\mathrm{N}}$ value of the diet by 5,13 and $5 \%$, respectively. The viscosity of jejunal digesta in the groups fed diets $\mathrm{RO}$ and $\mathrm{R}$ was comparable to the values found in the control and $\mathrm{LO}$ groups in Experiment 1. However, in group $\mathrm{R}$ the apparent protein and fat digestibility and $\mathrm{AME}_{\mathrm{N}}$ value were lower by $2.5,11$ and $6.4 \%$, respectively, in comparison with group RO. This indicates that fat and protein from rapeseed were not fully available for digestive enzymes of birds. Lowered fat extractability from rapeseed may arise from the presence of some deleterious complexes such as tannins and phytates (Matyka et al., 1992; Korol et al., 1994), while it seems that in linseed this effect was primarily connected with the high viscosity of dietary fibre.

There are a few reports concerning the effect of linseed or rapeseed on carcass yield. López-Ferrer et al. (2001) reported that replacing tallow by 20 or $40 \mathrm{~g} / \mathrm{kg}$ of linseed oil had a positive effect on carcass yield. Ajuyah et al. (1991) and Lee et al. (1991) showed that feeding diets containing $100 \mathrm{~g}$ canola or flaxseed per 
$\mathrm{kg}$ resulted in similar carcass yield as in the control group, but the breast muscle yield decreased. In the current study, the yield of meat in group L was reduced and the yield of skin with abdominal fat was similar to other groups. The chemical composition of edible and non-edible parts of the carcass differed slightly due to treatment, generally there was more fat in all parts of the body of chickens from group L, followed by the control group. The content of ash in non-edible parts of the carcass, which contained all bones, was significantly lower in group R, followed by group L. This may indicate a negative effect of phytates of both oilseeds on bone mineralization in chickens.

Total dietary crude fat content was similar in all diets. Erucic acid made up on average $0.54 \%$ of total FA in $\mathrm{R}$ and $\mathrm{RO}$ diets. The fatty acid profile of lipids in all parts of the broiler carcass reflected the composition of the dietary fat. The extent of changes was not affected by the form of fat inclusion into diet, i.e. as a component of full-fat seeds or as extracted oil. In spite of the rather large difference in SFA and MUFA content in diets, MUFA dominated in fat from different parts of the body in all groups, followed by SFA, which agrees well with other reports (Ajuyah et al., 1991; Pietras et al., 2000; Barteczko and Borowiec, 2001). In agreement with previous findings, oleic acid dominated among MUFA and palmitic acid dominated among SFA, followed by stearic acid. It is interesting that the degree of saturation of feather lipids (although their contribution to body fat was negligible) was much higher than in the body, due to a much higher content of stearic acid.

In the majority of research evaluating the effect of oilseeds, the FA profiles of breast, leg and adipose tissue (Barteczko and Borowiec, 2001) or even some defined breast and leg muscles without intramuscular fat (Olomu and Baracos, 1991) of chickens were compared, making it impossible to directly compare the FA profiles of samples prepared in this study according to a different methodology. However, our results support previous findings that in muscle lipids, the share of PUFA is greater than in lipids of abdominal fat. PUFA are preferentially incorporated into phospholipids, and the proportion of phospholipids in muscle lipids is higher than in lipids of adipose tissue (Van Elswyk, 1997).

The portion of the carcass designated in the study as meat, which made up from 42 to $45 \%$ of LBW, represented the most valued "lean" portion of the chicken carcass, but also contained intracellular and intramuscular fat. In comparison with control group, feeding diets with rapeseed or linseed oil reduced total SFA and raised the level of PUFA, particularly $\alpha$-linolenic acid in all parts of the carcass, in groups R and RO the level of PUFA was less elevated than in groups L and LO. The extent of changes was not affected by the form of introduction of fat into diet, i.e. as a component of full-fat seeds or as linseed oil. The greatest difference was in the proportion of n-6/n-3 PUFA, which in L and LO birds was 1.2-1.4, in $\mathrm{R}$ and $\mathrm{RO}$ birds about 4.7 , while in control birds about 10 . These results are quite consistent with previous reports (Ajuyah et al., 1991; Olomu and Baracos, 1991; 
Roth-Maier et al., 1998; Pietras et al., 2000; López-Ferrer et al., 2001). A ratio of n-6/n-3 PUFA no higher than 4:1 is recommended in human diets for the prevention of cardiovascular diseases (Van Elswyk, 1997). The n-6/n-3 PUFA ratio in meat of broiler chickens fed with rapeseed, linseed or respective oils would therefore appear to be more desirable for humans.

The fatty acid proportions in lipids of skin with subcutaneous and abdominal fat, which made up about $40 \%$ of total body fat, were similar as in meat. However, there were less PUFA with chains longer than 18 carbon atoms in this portion of the carcass than in meat, similarly as in reports by Ajuyah et al. (1991), Olomu and Baracos (1991) and López-Ferrer et al. (2001). In edible giblets and in non-edible parts of the carcass the trend and degree of changes of FA profile due to treatment were also similar as in meat.

It is interesting to compare the retention of n- 6 and n-3 PUFA in chicken bodies, as both linoleic and $\alpha$-linolenic acid are not synthesised by birds. Birds in the control group, which received on average only $4.8 \mathrm{~g}$ of $\mathrm{n}-3$ PUFA in the feed, retained 5.5 $\mathrm{g}$ of n-3 PUFA in the body, which may indicate a small extent of synthesis, while in $\mathrm{R}$ and $\mathrm{RO}$ groups, which received about $17.5 \mathrm{~g}$, and in groups $\mathrm{L}$ and $\mathrm{LO}$, which received on average $64 \mathrm{~g}$ of $\mathrm{n}-3$ PUFA in the feed, the retention of $\mathrm{n}-3$ PUFA averaged about $70 \%$. The intake of n-6 PUFA ranged from 58 in the control group to $81 \mathrm{~g}$ in group R, while the retention of these FA averaged $77 \%$ in groups fed diets with plant oils, in comparison with $87 \%$ in the control group. As a result, edible parts of chickens fed the diet with lard contained similar amounts of n-6 PUFA, but significantly less n-3 PUFA and had higher n-6/n-3 PUFA ratio, than birds fed diets with rapeseed and linseed oil or respective full-fat seeds. In general about $50 \%$ of PUFA consumed with diets containing both plant oils was found in edible parts of 6-week-old chickens.

\section{CONCLUSIONS}

Feeding a diet with $80 \mathrm{~g}$ linseed/kg, fortified additionally with pyridoxine, does not affect growth rate, but may worsen feed utilization and may slightly decrease the yield of meat, while linseed oil does not negatively affect the performance or slaughter yield of chickens. The diet containing $100 \mathrm{~g}$ rapeseed per $\mathrm{kg}$ of diet is well tolerated by broiler chickens and may not negatively affect their performance. Edible parts of broilers fed diets with rapeseed or its oil and linseed or its oil contained more n-3 PUFA and had a lower n-6/n-3 PUFA ratio than edible parts of chickens fed a diet supplemented only with animal fat. This shift may be considered as positive for consumers of broiler meat, as an increase of $n-3$ fatty acid intake is connected with health benefits in humans. 


\section{REFERENCES}

Ajuyah A.O., Lee K.H., Hardin R.T., Sim J.S., 1991. Changes in the yield and in the fatty acid composition of whole carcass and selected meat portions of broiler chickens fed full-fat oil seeds. Poultry Sci. 70, 2304-2314

AOAC, 1990. Official Methods of Analysis, Association of Official Analytical Chemists. 15th Edition. Chapter 32, Washington, DC

Barteczko J., Borowiec F., 2001. The fatty acid content in the tissues of broiler chickens fed diets containing a brown-seed linseed var. Opal or the yellow-seed var. Linola. J. Anim. Feed Sci. 10, Suppl. 2, 273-278

Borowiec F., Zając T., Kowalski Z.M., Micek P., Marciński M., 2001. Comparison of nutritive value of new commercial linseed oily cultivars for ruminants. J. Anim. Feed Sci. 10, 301-308

Bourdillon A., Carré B., Conan L., Francesch M., Fuentes M., Hughebaert G., Janssen W.M.M. A., Leclercq B., Lessire M., McNab J., Rigoni M., Wiseman J., 1990. European reference method of in vivo determination of metabolisable energy in poultry: reproducibility, effect of age, comparison with predicted values. Brit. Poultry Sci. 31, 567-576

Ekman P., Emanuelson H., Fransson A., 1949. The digestibility of protein in poultry. KGL. Lantbruks.Hogskol. Ann. 16, 749

Hill F.W., Anderson D.L., 1958. Comparison of metabolizable energy and productive energy determinations with growing chicks. J. Nutr. 64, 587-603

Hinsberg K., Cremer H.D., Schmid G., 1953. In: Hoppe-Seyler/Thierfelder-Handbuch der Physiologisch-und Patologisch-Chemischen Analyse. Springer-Verlag, Berlin, pp. 402-403

ISO-9167-1, 1991. HPLC method for Glucosinolates Estimation (in Polish). Polish Standards

Klosterman H.J., 1974. Vitamin B antagonist of natural origin. J. Agr. Food Chem. 22, 13-16

Korol W., Jaśkiewicz T., Bartuzi G., Bogusz G., Nieściór H., Grabowski C., Mojek E., 1994. Chemical composition of rape seed from low glucosinolate varieties grown in Poland. J. Anim. Feed Sci. $3,57-64$

Kracht W., Jeroch H., Matzke W., Ristic M., 1995. The influence of feeding 00-rapeseed on feed intake, growth performance and fatty acid composition of carcass fat. Proceedings of $9^{\text {th }}$ International Rapeseed Conference 'Rapeseed Today and Tomorrow', Cambridge (UK), Vol. 1, 176-178

Lee K.H., Olomu J.M., Sim J.S., 1991. Live performance, carcass yield, protein and energy retention of broiler chickens fed canola and flax full-fat seeds and the restored mixtures of meal and oil. Can. J. Anim. Sci. 71, 897-903

Leeson S., Atteh J.O., Summers J.D., 1987. Effects of increasing dietary levels of full-fat canola on performance, nutrient retention and bone mineralization. Poultry Sci. 66, 875-880

López-Ferrer S., Baucells M.D., Barroeta A.C., Galobart J., Grashorn M.A., 2001. n-3 enrichment of chicken meat. 2. Use of precursors of long-chain polyunsaturated fatty acids: Linseed oil. Poultry Sci. 80, 753-761

Madhusudhan K.T., Ramesh H.P., Ogawa T., Sasaoka K., Singh N., 1986. Detoxification of commercial linseed meal for use in broiler rations. Poultry Sci. 65, 164-171

Mazza G., Biliaderis C.G., 1989. Functional properties of flax seed mucilage. J. Food Sci. 54, 13021305

Matyka S., Jaśkiewicz T., Bogusz G., Korol W., 1992. A note on the chemical composition of low glucosinolate rape seed produced in North-Eastern Poland. J. Anim. Feed. Sci. 1, 177-182

National Research Council, 1994. Nutrient Requirements of Poultry. 9th Edition. National Academic Press, Washington, DC

Nguyen C.V., Smulikowska S., Mieczkowska A., 2001. Effect of antinutritional factors of flax seeds on performance of broiler chicken (in Polish). Rośliny Oleiste 22 (1), 153-160

Olomu J.M., Baracos V.E., 1991. Influence of dietary flaxseed oil on the performance, muscle protein deposition, and fatty acid composition of broiler chicks. Poultry Sci. 70, 1403-1411

Ortiz L.T., Rebolé A., Alzueta C., Rodriguez M.L., Trevino J., 2001. Metabolizable energy value and digestibility of fat and fatty acids in linseed determined with growing broiler chickens. Brit. Poultry Sci. 42, 57-63 
Paterson E., Amado R., 1997. Simplified method for simultaneous gas chromatographic determination of fatty acid composition and cholesterol in food. Lebensm.-Wiss. Tech. 30, 202-209

Pietras M., Barowicz T., Gasior R., 2000. The effect of vegetable fat supplements on carcass quality and fatty acid profile of meat in broiler chickens. Ann. Anim. Sci. - Rocz. Nauk. Zoot. 27(4), 209-219

Rodriguez M.L., Alzueta C., Rebolé A., Ortiz L. T., Centeno C., Trevino J., 2001. Effect of inclusion level of linseed on the nutrient utilisation of diets for growing broiler chickens. Brit. Poultry Sci. $42,368-375$

Rotenberg S., Andersen J., 1980. The effect of dietary citrus pectin on fatty acid balance and on fatty acid content of the liver and small intestine in rats. Acta Agr. Scand. 30, 8-12

Roth-Maier D.A., Eder K., Kirchgessner M., 1998. Live performance and fatty acid composition of meat in broiler chickens fed diets with various amounts of ground or whole flaxseed. J. Anim. Physiol. Anim. Nutr. 79, 260-268

Statgraphics ${ }^{\circledR}$ ver. 5.1., 1994-2001. Statistical Graphics System by Statistical Graphic Corporation (USA)

Van Elswyk M.E., 1997. Nutritional and physiological effects of flax seed in diets for laying fowl. World Poultry Sci. J. 53, 253-264

Wałkowski T., Krzymański J., Bartkowiak-Broda I., Mrówczyński M., Korbas M., Paradowski A., Ochodzki P., 2000-2001. Winter Rape (in Polish). Plant Breeding and Acclimatization Institute (Editor). Poznań (Poland)

\section{STRESZCZENIE}

\section{Wpływ nasion Inu i rzepaku oraz oleju Inianego i rzepakowego na wyniki odchowu, wydajność rzeźną oraz odłożenie kwasów tluszczowych w jadalnych częściach ciała kurcząt brojlerów}

Celem pracy było zbadanie wpływu nasion lnu i rzepaku oraz oleju lnianego i rzepakowego na wyniki odchowu, strawność składników pokarmowych, wartość energii metabolicznej diet, lepkość treści pokarmowej oraz wydajność i skład chemiczny jadalnych i niejadalnych części tuszy ze szczególnym uwzględnieniem n-3 PUFA.

Przeprowadzono 2 doświadczenia na 134 kurkach brojlerach, przydzielonych losowo do 3 grup po 22 ptaki (Doświadczenie 1) i do 2 grup po 24 ptaki (Doświadczenie 2) oraz po 10 ptaków do grupy zerowej. Kurczęta utrzymywano w indywidualnych klatkach. Przygotowano 5 izobiałkowych diet pszenno-sojowych uzupełnionych ksylanazą, zawierających $80 \mathrm{~g}$ thuszczu surowego w $\mathrm{kg}$. Do diety kontrolnej (C) dodano smalec $(61 \mathrm{~g} / \mathrm{kg})$, w doświadczeniu $1 \mathrm{w}$ diecie LO połowę smalcu zastapiono olejem lnianym, w diecie L nasionami lnu, w doświadczeniu 2 w diecie RO olejem rzepakowym, w diecie R nasionami rzepaku 00. Diety podawano do woli od 8 do 42 dnia życia, po czym kurczęta ubito, podzielono tuszki na części jadalne i niejadalne i oznaczono ich skład chemiczny.

Dodatek nasion rzepaku lub oleju rzepakowego do diety nie wpłynął w sposób istotny na przyrost masy ciała ani na wykorzystanie paszy, natomiast dodatek nasion lnu spowodował zwiększenie pobrania paszy i pogorszenie jej wykorzystania, które wynosiło 1,73; 1,82 i $2 \mathrm{~kg} / \mathrm{kg}$, odpowiednio w grupach $\mathrm{LO}, \mathrm{C}$ i L $(\mathrm{P} \leq 0,05)$. Lepkość treści jelita czczego u kurcząt $\mathrm{z}$ grupy $\mathrm{L}$ wynosiła średnio 4,5 , podczas gdy w pozostałych grupach średnio 1,6 mPas.s. Strawność tłuszczu i retencja masy organicznej oraz wartość energii metabolicznej diety w grupie L były mniejsze niż w grupach C i LO $(\mathrm{P} \leq 0,05)$, w grupie R mniejsze niż w RO $(\mathrm{P} \leq 0,01)$. Retencja białka i wydajność mięsa u 42-dniowych kurcząt były mniejsze w grupie L niż w obydwóch pozostałych grupach

W tuszkach kurcząt z grup R i RO odłożenie n-3 PUFA było o około 2 razy większe, a z grup LO i L 8 razy większe niż w tuszkach kurcząt z grupy kontrolnej. Stosunek n-6/n-3 PUFA, który wynosił około $10 \mathrm{w}$ częściach jadalnych tuszek z grupy kontrolnej, w tuszkach kurcząt z grup R i RO obniżył się do 4,7, z grup L i LO do 1,3, co korzystnie wpłynęło na ich wartość dietetyczną. 